\title{
The Application of E-mail to College English Teaching in China
}

\author{
Guofeng Wang \\ Foreign Languages Department, Shandong Institute of Business and Technology \\ 191 Binhai Middle Road, Yantai, China 264005 \\ E-mail: wangguofeng77@163.com
}

\begin{abstract}
With the development of information technology in the past 10 years, e-mail has been widely used in the field of English teaching. This paper, based on an analysis of the ways of using e-mail in college English teaching in China, probes the feasibility and the benefits of application of e-mail to college English teaching.
\end{abstract}

Keywords: E-mail, College English teaching, Ways of using e-mail, Feasibility and benefits

\section{Introduction}

With the fast development of computer and digital information technology (including multi-media technology, internet technology, mobile telecommunication technology and wireless network technology), computer and internet are combined more and more with language teaching, on the basis of which e-learning environment has been constructed. Computer Assisted Instruction (CAI) has been widely used in many developed countries. However, computer and internet don't play important role in the scope of language teaching in China. For instance, as one of the most widely used and the most convenient means of communication, e-mail is seldom used in the college English teaching and learning. Instead, it is simply used as a communication tool by the teachers and students in China. But in some western countries, together with other internet tools, e-mail began to be widely used in many fields like mathematics, scientific research. It's estimated that there are more than 1 billion e-mail users all over the world (Mark W. 1995:5). So how to make good use of e-mail in college English teaching has become one of the heated topics.

\section{The feasibility of application of e-mail to the college English teaching}

The striking characteristics of e-mail make it possible to be applied to the college English teaching.

2.1 E-mail can send large amount of information easily and conveniently. E-mail is a very powerful information tool that is simple to use and easy to understand. It's hard to imagine any other form of computer-based communication that can be so intimate and yet so wide reaching --- so focused and so expansive (Ken W. White \& Jason D. Baker 2004: 44).The present college English teaching puts much emphasis on listening, speaking, reading, writing and translation. Therefore, the teachers need to provide the students with various learning materials and get the feedback from students in time, which results in the exchange of a large amount of information between teachers and students. But it is very difficult to realize this exchange in the traditional English teaching classroom. With the help of e-mail, however, this can be realized easily. A single optical fiber with a diameter of less than half a millimeter can transfer all the information contained in the 29 volumes of Encyclopedia Britannica in one second. So teachers and students can exchange information easily with the help of e-mail.

2.2 E-mail can provide a real and natural environment for the students to study English. The best way to study English well is to use it. One fact we have to admit is that there is no authentic language environment for the Chinese students to practice and use English, which results in the divorce between study and application which is bitterly criticized by many experts and scholars. But the Chinese students can effectively improve their English levels by communicating with people whose mother tongue is English through e-mail. This e-communication can enable Chinese students to learn some authentic English expressions which can not be found in the textbooks and to become more confident as well.

2.3 E-mail can improve students' ability of Independent Learning. In traditional English teaching classroom it's impossible for the teachers to answer all the questions from students, and when the class is over the synchronous communication between teachers and students is over too. Most students don't want to ask the teacher questions face to face for the sake of shyness, which prevents them from improving their English. But e-mail can realize the asynchronous computer-mediated communication between teachers and students. Many students who might hesitate to ask questions in person are much more forthright via e-mail (Mark W. 2000: 32). They can communicate with their teachers, classmates and even teachers and students from other universities without fearing of shyness via e-mail. This is virtually one of the positive ways of independent learning. 
2.4 E-mail is very helpful for the teachers to improve their own learning. English teachers can share teaching experience, ideas, methodology, materials by communicating with English teachers from other universities both at home and abroad via e-mail to break the limits and to improve their English.

\section{The application of e-mail to the college English teaching}

The application of e-mail to the college English teaching can be realized through the following ways: teacher-teacher interaction, teacher-student interaction and student-student interaction.

\subsection{Teacher-teacher ( $t-t)$ interaction}

"You cannot make bricks without straw." If an English teacher wants to improve his teaching skills, he has to acquire more knowledge and better his teaching approaches. But the individual and closed study prevents the teachers from making quite great progress. Therefore, more exchanges of information among teachers are called for. In fact, the exchanges of teaching experience and learning among teachers are limited to one or several universities in a certain area and teachers can only improve their teaching, academic and reach levels by depending on the few academic journals and magazines, which greatly restricted the development of the teachers themselves as well as the field of English teaching. Fortunately, this situation has been changed due to the rapid development of internet in the way that the worldwide teaching and scientific research resources can be shared by all. College English teachers can exchange ideas on English teaching with language experts and academic journals via e-mail. The advantages of e-mail use for teachers include: access to professional development forums; the opportunity to contact colleagues and share practice; and the ability to forge links that benefit the school (Ictadvice 2003). We can find some e-mails which can make us reach to some academic journals and experts, for instance, celea@fltrp.com (for Foreign Language Teaching and Research Press),bwyys@bfsu.edu.cn (for Foreign Language Teaching and Research ), elt@fltrp.com (for Teaching English in China), and so on and so forth. Apart from this, English teachers can discuss English teaching with their counterparts from other countries and regions all over the world through e-mail discussion lists. Some famous are TESL-L Discussion List(Teachers of English as Second Language Discussion List, the website is http://www.hunter.cuny.edu/ tesl-l/).TESL-L was founded in May, 1991, with the goal of providing educators with a fast, convenient, and topical electronic discussion forum that focuses on issues related to TESL/TEFL. It maintains cordial relationships with all professional organizations in the field of English language education, including TESOL (Teachers of English to Speakers of Other Languages) and IATEFL (International Association of Teachers of English as a Foreign Language). The registered user can put forward any questions about English teaching and discuss the questions with over ten thousand English teachers around the world. By September 15, 2006, it has 32,293 members in 172 countries. Some other e-mail discussion lists are as follows:

English Forum (http://www.Englishforums.com/)

The English Learner / Diversity Listserv (http://www.aea11.k12.ia.us/site/listserv/index.html)

Linguist List (http://linguistlist.org/LL/subs-index.cfm)

Linguistics Lists (http://linguistlist.org/lists/index.html)

NIFL-ESL (http://www.nifl.gov/lincs/discussions/discussions.html)

TEFL CHINA (http://teflchina.com)

SLART-L (Second Language Acquisition Research and Teaching List)

(http://listserv.cuny.edu/archives/slart-l.html)

English Teaching forum Online (http://exchanges.state.gov/forum/)

The worldwide English teachers can take part in the activities on this discussion lists. Undoubtedly, this will stimulate the academic exchanges among the English teachers all over the world and in turn improve the English teaching. Besides, the teachers from the same university or department can communicate more frequently with each other about teaching experience and strengthen cooperation in teaching and scientific research so that they can play more important role as a teaching team.

\subsection{Teacher-student $(t-s)$ interaction}

As more and more high school students are now admitted to universities, English is often taught in a classroom jammed with about over100 students. In Shandong Institute of Business and Technology (SDIBT), for example, there were 158 students in my class 2 years ago. Now the situation is better, but there are still 81 students in my class. Class participation is an awkward and terrifying experience for most students. Frustration is universal and perpetual over the limited opportunity for participating. Many questions about English learning from students 
can not be solved in time during the regular classroom teaching. Teachers and students seldom have face-to-face communication after class due to the lack of proper time, the lack of confidence in English study or mere shyness (Mark W. 1995:33). This insufficiency of communication has a negative influence on the college English teaching and learning and ruins the enthusiasm of both the teachers and the students to teach and study English. In such a case, the employment of e-mail might be good solution to this problem. It is just like a bridge between teachers and students for their all-round communication both in and after class. To some extent, this communication bridges the gap between the teachers and the students and makes it more like "communication between colleagues"(Donald, E.H., Michelle, G. \& Simone 2000:10). The ways to realize teacher-student interaction via e-mail are as follows:

\subsubsection{Problem solving and question answering}

Just like what we have discuss above, many questions from students can not be solved by teachers in time during the regular class time, but this can be easily done via e-mail after class. A teacher in New York University conducted a study on the informal working time via e-mail and the result showed that his students not only consulted him more often but also became opener and better at communication (Mark W. 1995:33). Many students always hesitate to ask questions when face to face with teachers, but they became bold and frank to ask without any worry via e-mail(Mark W. 2000:32). I ever conducted an experiment in the class which I taught in 2003. There are 81 students all together in the class. In the first semester, I told my students to ask me directly in or after class if they had any questions about English study, but the result was quite disappointing. Only very few students came to me to consult immediately when class was over. What surprised most was that nobody came to me to consult after class in spite of the fact that they did have a lot of questions. So at the very beginning of the second semester, I made some changes by telling them my e-mail address. I told them they could send their questions to me via e-mail and I would answer every e-mail. The result turned to be beyond expectation. All the students became very active to send me e-mails asking many questions about English learning. They sent me 492 emails in total. Table 1 just tells us what the students are interested in about English learning. (Insert table 1 here)

From table 1 we can see that the content of the e-mail covered various aspects: English study, personal greetings for me and even problems they encountered in their daily life. As what I ever told them, I answered all the e-mails. My students agree that they get great help from me via email. One of the advantages of this method is that if I find many students share the same question in common, I can spare some time to explain it in class. This is time-saving and joints the class study and after-class study closely.

\subsubsection{Language abilities developing}

E-mail is quite useful to develop the abilities of listening, reading, and writing. The experiment I made in my class showed the effects of e-mail in developing these abilities.

In order to give a full play to e-mail in developing the language abilities, I applied for a special e-mail t-scommunication@163.com firstly, and made it public to all my students, telling them the code to log on. This e-mail address became a bridge between the students and I. I tried to train and develop my students' abilities of listening, reading and writing.

\subsubsection{Developing listening ability}

When it comes to listening, e-mail shows its advantages: convenient, swift and voluminous. I made some mp3 or wma. (Because these 2 can be played by mp3 or mp4 player) audio listening materials by myself with the help of computer technology or searched them on the internet. Then I classified them into Band A and Band B according to their difficulty and uploaded them into the net disk in the public e-mail box. The students could choose to listen to Band A or Band B according to their own English level. They could download these audio listening materials to their $\mathrm{mp} 3$ or $\mathrm{mp} 4$ players for free listening or listen online. Whatever method they choose, they have to understand the materials before a set deadline. When the deadline came, I checked how much they understood. It turned out that the students' listening ability was improved greatly. Compared with the traditional way to improve listening with tape-recorder and magnetic tape, the biggest advantage is that the listening materials can be renewed very quickly so that students can listen more, and they can choose the right listening materials which suit their English level.

\subsubsection{Developing reading ability}

E-mail can play an even more important role in developing reading ability. In traditional English teaching, it's impossible for the teachers to hand out as many reading materials as possible to the students because of large number of students and the lack of fund, which limits the improvement of the students' reading ability. E-mail is definitely a good answer to this problem. I collected some reading materials on the internet which includes some 
from Band 4 and Band 6 (this can be done very easily on the internet) and some passages from China Daily, $21^{\text {st }}$ Century and some other English websites. Then I edited and designed these materials by adding and deleting something and designing some questions. After that, I uploaded them to the public mailbox. The students were requested to send the answers to me via e-mail for my check within a fixed period. The students can get access to several hundred pages of reading materials at one time very easily. The extensive reading can definitely be very helpful for the students to improve their reading ability.

\subsubsection{Developing writing ability}

E-mail has shown its great usefulness in improving students' writing ability. Many experts and scholars both from home and abroad ever wrote essays, dwelling on this point in great details, for example, Janice Cook (1996) from Honolulu Kapiolani Community College, University of Hawaii, Ellen Pratt (1996) from University of Puerto Rico and Nancy Sullivan (1996) from Texas A\&M University, Hartman (1991), Mabrito(1991,1992), Kern.R. G.(1993), Palmquist M. (1991). The results of their experiments and research all showed that the use of e-mail in English writing could definitely enhance students' writing ability. Pratt \& Sullivan (1996) conducted a research at University of Puerto Rico which lasted one semester, aiming at studying the effects of writing with the help of computer. They compared students in two English-as-a-Second-Language writing environments: a networked computer-assisted classroom and a traditional oral classroom. Results indicated that while the writing environment has no effect on attitudes toward writing with computers or writing apprehension, writing quality improves in the computer-assisted classroom and that discourse patterns in the two environments are different. "Students become more confident in writing", "every word they put down is not for the purpose of being corrected by their teacher, but rather for the purpose of sharing ideas with their classmates"(Mark W. 1995: 40).

I did similar experiment in the class I taught in 2004. In the last semester, I asked my students to hand in their English composition via e-mail instead of the traditional exercise book. I made it clear that they should draft and edit their composition with Office Word processing tool. The result was that the quality of the composition handed in via e-mail was greatly improved. The spelling and grammatical mistakes which used to be common decreased to a very low level because the Office Word processing tool has the function of marking the spelling and grammatical mistakes automatically, so the students could find their mistakes and corrected them in time. The mistakes are usually so impressive that students will not make the same mistakes in the future. The high quality compositions also reduce teachers' heavy burden to a great extent. The application of e-mail to the writing liberates both the teachers and the students from the old traditional method, which makes the study a process full of findings, thoughts, explorations, creations and excitement.

There are two more benefits to collect the compositions via e-mail and public e-mailbox. One is that since all the students' compositions are stored in the same mailbox, anyone can log onto the mailbox to do peer-reading. It's usually difficult for us to notice the errors we make in our own composition, but it's an easy thing to find the mistake in other's compositions. By doing peer-reading, the students can raise their mistake-free awareness. They can make their compositions free from some easy mistakes. The other benefit is that teachers can establish their own corpus which is composed of the compositions, which can provide materials for scientific research. For example, there were 158 students in the class I taught in grade 2004. Every student was asked to handed in 1 composition every week during a 16-week semester. The total number of the composition in the whole semester should be 2528. Yes, some students didn't hand in compositions, so the virtual number was about 2000. I keep doing so, it is no longer a dream to have one's own corpus.

Apart from what we discussed above, more benefits can be seen in this writing method. For instance, the students are on equality with each other. "For those who are not confident and shy, they needn't to bother other students. They can write at their own speed."(Kroonenberg 1994/1995). Kern, R. G. (1995a) and Mark W. (1996) think all students can "speak", giving shy students a greater chance to participate. Mark W. (1999) also think students can notice, refer to, save, and reuse input, which allows them to assimilate vocabulary, collocations and grammar. They have more control over the planning time for their output,, which allows them to reach for more complex terms.

\subsection{Student-student (s-s) interaction}

According to my observation and inquiry, the college students make very few communications concerning English study both in class and after class. In their opinion, this is mainly due to the lack of a platform for communication. The lack of the fixed classroom and their shyness prevent them from further communication. I ever made a survey in the class of Grade 2004 which I taught and the results can be seen in the following table. (Insert table 2 and table 3 here)

From Table2 and Table3 we can come to a conclusion that the students communicate very little about English 
study after class and the main reasons are the lack of fixed communicative media and shyness. However, e-mail can provide the students with a stable and convenient medium for them to communicate. They can communicate with each other about English study through e-mail, which broadens the English study from classroom to everywhere. What's important is that students enhance their friendship by doing so. Janda designed a series of activities on the basis of e-mail, encouraging the cooperative communication and writing among students. In these activities students were required to do group-work, introducing to each other, discussing movies and literary works and preparing oral presentations, and so on and so forth (Janda 1995). Manteghi designed chain stories (with one student writing after the other). The teacher starts the story with one student continuing and e-mailing to another student until every student writes a part of the story (Manteghi 1995).

Student-student interaction through e-mail can enlarge the content of teaching effectively, but some points should be paid much attention to:

(1). Remember that careful planning in advance is quite necessary for activities through e-mail. Don't take it for granted that students can make good use of it independently.

(2). Teachers should act as an active guide but not a controller. In the background of web-based teaching, it's the teachers' purpose to let the students learn how to control their study so that they can master the skills for independent learning (Lai, K. W. 2001:43)

(3). Think of it carefully how to integrate the e-mail-based activities after class with the regular classroom study effectively. Kern assumes that electronic discussion can be an excellent preparation for an oral discussion on the same activity (kern, R.G .1995b).

(4). In the activities through e-mail, teachers should not correct the mistakes made by the students directly. Instead, they should let students know the correct way to express by setting examples. (Kelm 1995)

\section{Conclusion}

Undoubtedly, the biggest change brought about by online education is that the cooperation between teachers and students is strengthened more and more (Greg, K. 2000: 4). We can draw a conclusion from the above analysis that students' initiatives and interests will be greatly aroused if the teachers make good use of e-mail in the English teaching. But we have to acknowledge that nothing can take the place of teacher in the teaching activities. Teachers should catch up with the development of the technology by acquiring the modern teaching methods so that they can help the students benefit as much as possible from the use of e-mail.

\section{References}

Donald, E.H., Michelle, G. \& Simone, C. (2000). 147 practical Tips for teaching online groups. Wisconsin: ATWOOD PUBLISHING.

Greg, K. (2000). Online education: learning and teaching in cyberspace. Belmont: Wadsworth.

Ictadvice (2003). What are the management issues of teacher access to web and e-mail? (at http://schools.becta.org.uk)

Janda, T. (1995). Breaking the ice: e-mail dialogue journal introductions and responses. In Mark W. Virtual connections: online activities and projects for networking language learners (pp. 57-58). Honolulu: University of Hawaii, Second Language Teaching and Curriculum Center.

Ken, W. W. \& Jason, D. B. (2004). The student guide to successful online learning. Boston: Pearson Education. Inc.

Kern, R. G. (1995a). Decouvrir Berkeley: Student's representation of their world on the World Wide Web. In Mark W. Virtual connections: online activities and projects for networking language learners (pp. 355-356). Honolulu: University of Hawaii, Second Language Teaching and Curriculum Center.

Kern, R. G. (1995b). Restructuring classroom interaction with networked computers: Effects on quantity and quality of language production. Modern Language Journal, 79, 457-476.

Kelm, O. (1995). E-mail discussion groups in foreign language education: Grammar follow-up. In Mark W. (Ed.), Telecollaboration in foreign language learning: proceedings of the Hawaii Symposium (pp. 19-28). Honolulu: University of Hawaii, Second Language Teaching and Curriculum Center.

Kroonenberg, N. (1994/1995). Developing communicative and thinking skills via electronic mail. TESOL Journal, 4(2),24-27.

Lai, K. W. (2001). E-learning: teaching and professional development with the internet. Dunedin: University of 
Otego Press.

Manteghi, C. (1995). The collaborative fairy tale. In Mark W. Virtual connections: online activities and projects for networking language learners (pp. 20-22). Honolulu: University of Hawaii, Second Language Teaching and Curriculum Center.

Mark, G. \& Cindy, G. (2000). Integrating the internet for meaningful learning. New York: Houghton Mifflin Company.

Mark W. (1995). E-mail for English teaching. Washington DC: TESOL.

Mark W., Heidi S. \& Christine M. (2000). Internet for English teaching. Alexandria: TESOL.

Mark W. (1996). Comparing face-to-face and electronic communication in the second language classroom. CALICO Journal, 13(2), 7-26.

Mark W. (1999). Electronic literacies: language, culture, and power in online education. Mahwah, NJ: Erlbaum.

Schultz, J. (2000). Computers and collaborative writing in the foreign language curriculum. In M.Warschauer \& R. Kern. Network-based language teaching: Concepts and practice (pp.121-150). Cambridge: Cambridge university Press.

Table 1. Students' questions about English learning

\begin{tabular}{|l|l|l|}
\hline & $\mathrm{CN}=492$ \\
\hline Grammar & 21 & $4.3 \%$ \\
\hline Vocabulary & 83 & $16.9 \%$ \\
\hline listening & 98 & $19.9 \%$ \\
\hline Reading & 76 & $15.4 \%$ \\
\hline Writing & 75 & $15.2 \%$ \\
\hline speaking & 81 & $16.5 \%$ \\
\hline $\begin{array}{l}\text { Cultivating interests } \\
\text { in English }\end{array}$ & 47 & $9.6 \%$ \\
\hline Others & 11 & $2.2 \%$ \\
\hline
\end{tabular}

Table 2. Frequency of s-s communication

\begin{tabular}{|l|l|l|}
\hline Frequency & \multicolumn{2}{|l|}{ Number of students } \\
\hline Often $(>3$ per week $)$ & 18 & $11.4 \%$ \\
\hline Occasionally $(<1$ per week $)$ & 47 & 29.7 \\
\hline Never & 93 & 58.9 \\
\hline
\end{tabular}

Table 3. Factors preventing the student-student communication

\begin{tabular}{|l|c|c|}
\hline Factors preventing s-s communication & \multicolumn{2}{|c|}{ Number of students } \\
\hline Lack of communicative media & 89 & $56.3 \%$ \\
\hline Not knowing whom to talk to & 16 & $10.1 \%$ \\
\hline Not knowing what to talk about & 21 & $13.3 \%$ \\
\hline Shyness & 30 & $19 \%$ \\
\hline Others & 2 & $1.3 \%$ \\
\hline
\end{tabular}

